\title{
Growth and feed utilization of the shrimp Farfantepenaeus paulensis fed diets containing different marine protein sources
}

\author{
Crescimento e eficiência alimentar do camarão Farfantepenaeus paulensis alimentado com \\ dietas contendo diferentes fontes protéicas marinhas
}

\author{
Ronaldo Olivera Cavalli ${ }^{1}$ Sérgio Zimmermann ${ }^{2}$ Roger Crippa Speck
}

\section{ABSTRACT}

Five isonitrogenous and isoenergetic diets containing different protein sources (fish, squid and mussel meals and their combinations at the proportions of 40, 30 and $30 \%$ or 60, 20 and 20\%) were fed for 28 days to Farfantepenaeus paulensis. Growth performance and feed utilization of shrimp fed the fish meal-based diet was comparatively inferior to those fed other protein sources or their combinations. This indicates that fish meal may not be the best protein source for $\boldsymbol{F}$. paulensis. Feeds containing a mixture of protein sources are better utilized by $\boldsymbol{F}$. paulensis and therefore result in significantly higher growth than those containing a single protein source.

Key words: shrimp, Farfantepenaeus paulensis, growth, feed utilization, protein sources

\section{RESUMO}

Cinco dietas iso-protéicas e iso-energéticas contendo diferentes fontes de proteína marinhas (farinhas de peixe, lula e mexilhão e suas misturas nas proporções de 40, 30 e 30\% ou 60, 20 e 20\%) foram oferecidas durante 28 dias para o camarão Farfantepenaeus paulensis. $O$ crescimento e a taxa de conversão alimentar dos camarões arraçoados com a dieta a base de farinha de peixe tendeu a ser inferior àqueles alimentados com as outras fontes de proteína elou suas combinações. Estes resultados indicam que a farinha de peixe pode não ser a melhor fonte protéica para $\boldsymbol{F}$. paulensis. Dietas contendo uma mistura de fontes protéicas foram mais bem utilizadas por $\boldsymbol{F}$. paulensis $e$, portanto, resultaram em taxas de crescimento superiores àquelas contendo uma única fonte de proteína.

Palavras-chave: camarão, Farfantepenaeus paulensis, crescimento, eficiência alimentar, fontes de proteína.

\section{INTRODUCTION}

In the last few years, the culture of penaeid shrimp has taken an increasingly important place in Brazil (BARBIERI, 1999). Production has increased from 2,650 metric tons in 1995 to 60,128 metric tons in 2002 (ROCHA \& RODRIGUES, 2003) and is based mainly in the culture of Litopenaeus vannamei in northeastern Brazil. Nevertheless, the farming of Farfantepenaeus paulensis has demonstrated promising results when cultured in earthen ponds (BUENO, 1989; PEIXOTO et al., 2003) or in alternative grow-out structures (WASIELESKY et al., 2002). Attributes favorable to the culture of this species include successful reproduction and larval rearing in captivity (MARCHIORI, 1996), absence of major disease problems, and the ability to grow at relatively low temperatures (OLIVERA et al., 1993; PEIXOTO et al., 2003).

Although feed is considered the largest production cost for commercial shrimp culture (AKIYAMA et al., 1992), very little information is available concerning the nutritional requirements of F. paulensis. MARCHIORI et al. (1982) indicated that animal protein sources probably have a higher nutritional value for this species than plant proteins, but ITO et al. (1996) showed that up to $60 \%$ of the dietary protein could be of plant origin with no significant decrease in the growth of $\boldsymbol{F}$. paulensis

\footnotetext{
${ }^{1}$ Engenheiro Agrônomo, Doutor, Professor Adjunto, Fundação Universidade Federal do Rio Grande (FURG), Departamento de Oceanografia, Estação Marinha de Aquacultura, CP 474, 96201-900, Rio Grande, RS, Brazil. E-mail: Cavalli@mikrus.com.br. Corresponding author

${ }^{2}$ Engenheiro Agrônomo, Mestre, Professor Adjunto, Universidade Luterana do Brasil, Rua Miguel Tostes, 101, Bairro São Luís, 92420280, Canoas, RS, Brazil.

${ }^{3}$ Oceanólogo, graduado pela FURG.
} 
juveniles. RODRIGUES (1985) used a fish mealbased diet and estimated $45 \%$ as the optimal crude protein level. However, requirements for protein and energy may vary at different environmental salinity levels (DIAZ, 1995). As a result of the scarcity of information on the nutritional requirements of this species, the inexistence of adequate feeds to sustain profitable production (LEMOS et al., 2000) has been pointed out as one of the causes for the decrease in the culture area of $\boldsymbol{F}$. paulensis over the last few years.

The present work was designed to assess whether practical diets containing different protein sources of marine origin would affect growth performance and feed utilization of $\boldsymbol{F}$. paulensis. These data may provide baseline information on the relative importance of the different marine protein sources available for the formulation of adequate diets for this species.

\section{MATERIAL AND METHODS}

Shrimp were obtained from a routine larviculture carried out at the Estação Marinha de Aquacultura - FURG, Brazil. At the beginning of the experiment, a sample of 100 shrimp was randomly selected, weighed to the nearest $0.01 \mathrm{mg}$ after blotting and used as a reference. Initial wet weight was $2.53 \pm$ $0.04 \mathrm{mg}$. Groups of 100 shrimp were transferred to 15 plastic tanks containing 100 liters of water at a salinity of $29 \pm 1$. Gentle aeration was provided by one air stone per tank. Temperature was maintained with submerged electric heaters equipped with thermostats. At least $10 \%$ of the total water volume was renewed daily. The experiment was conducted during January and February, hence a natural summer photoperiod was applied.

Five practical diets were formulated to be isonitrogenous and isoenergetic (Table 1). These diets were basically an adaptation of the egg custard technique, which is usually employed in the culture of freshwater prawns (NEW \& SINGHOLKA, 1995). Although the experimental diets shared a common basal portion made from a mixture of whole hen eggs and dry ingredients, they differed in their main protein source. Fish, squid and mussel meals were added either separately or in combination. Diets were therefore named as "Fish", "Squid", "Mussel", "Mix 1" or "Mix 2" when their main protein source were either fish meal, squid meal, mussel meal, or the combination of these 3 ingredients in the proportions (w/w) of 60,20 and $20 \%$ or 40,30 and $30 \%$, respectively.
Around $300 \mathrm{ml}$ of water was added to the dietary ingredients before homogenization in a blender. This mixture was placed in a microwave oven for 5-6 minutes and then air-dried for 1-2 hours. The cooked custard was sieved into particles of $300-850 \mathrm{~mm}$ and refrigerated until use. Proximate analyses for percentage moisture, crude protein, crude fat, ash and crude fiber of the diets were performed using standard techniques (AOAC, 1984). The percentage of nitrogen free extract was determined by difference. Since neither digestible nor metabolizable energy values are available, dietary energy values were estimated using standard physiological fuel levels of 4.1, 5.6 and $9.5 \mathrm{kcal} / \mathrm{g}$ for carbohydrates, protein and lipids, respectively (CHO et al., 1982).

Shrimp were fed to excess twice daily: one third was distributed at around $9 \mathrm{~h}$, while the remaining two thirds were offered at $17 \mathrm{~h}$. The daily amount of feed offered per tank increased progressively: $0.11 \mathrm{~g}$ until day $8,0.24 \mathrm{~g}$ until day $16,0.30 \mathrm{~g}$ until day 24 and $0.40 \mathrm{~g}$ afterwards. Feces and uneaten feed were siphoned out daily from each tank.

The instantaneous growth rate $(\mathrm{G})$ was calculated following BAGENAL (1978): $\mathrm{G}=(\ln W$ $-\ln \mathrm{W}) / \Delta \mathrm{T}$, where Wf and Wi represent the final and initial weight, respectively, and $\Delta \mathrm{T}$, the duration of the experimental period. Apparent feed conversion ratio (FCR) was estimated as the total dry weight of feed offered per tank divided by the wet weight gain, while the protein efficiency ratio (PER) was calculated as the wet weight gain in relation to the total weight of protein fed to shrimp in each tank.

Water quality parameters monitored during the experimental period included temperature, salinity, $\mathrm{pH}$, total ammonia and nitrite. Temperature, salinity and $\mathrm{pH}$ were measured daily with a hand-held thermometer $\left(10\right.$ to $\left.50^{\circ} \mathrm{C}\right)$, an optical refractometer (ATAGO) and a pH-meter (DIGIMED DMpH-1), respectively. Total ammonia and nitrite were determined once a week following the procedures of SOLORZANO (1969) and BENDSCHNEIDER \& ROBINSON (1952), respectively.

The experiment consisted of a completely randomized design with three replicates for each of the five dietary treatments. Statistical analysis of the data included one-way analysis of variance (ANOVA) and, where appropriate, Duncan's multiple range test was applied. Differences were considered to be significant at 5\%. Prior to analysis survival data were arcsine-square root transformed, but untransformed values are presented here. All data are presented as means \pm standard deviation $(\mathrm{SD})$. 


\section{RESULTS}

Temperature was maintained at $24-27^{\circ} \mathrm{C}$, salinity ranged from 28 to 31 and $\mathrm{pH}$ was $8.21 \pm$ 0.09 (Table 2). Total ammonia remained below $0.35 \mathrm{mg} / \mathrm{l}$ throughout the experimental period, while nitrite did not exceed $0.08 \mathrm{mg} / \mathrm{l}$. Water quality was not considered to be detrimental to the survival and growth of $\boldsymbol{F}$. paulensis in the present study.

The analysis of the proximate composition of the experimental diets revealed that crude protein levels were quite similar, ranging from 47.1 to $49.0 \%$ (Table 1 ). The contents of fat, ash, fiber and nitrogen free extract were also comparable among the different diets.

At the end of the feeding trial, mean survival rates were above $80 \%$ (Table 3 ). Survival of the shrimp fed the Mix 2 diet (mixture of fish, squid and mussel at a ratio of 40,30 and $30 \%$, respectively) was significantly higher than those fed the Mussel diet. No significant differences among means were found between the other treatments.

After 28 days of culture, shrimp had reached significantly different wet weights (Table 3 ) with those fed the diet Mix 2 presenting significantly higher weight and biomass than those fed the diet containing fish meal as the main protein source. Final weight and biomass of shrimp fed the diets Squid, Mussel or Mix 1 did not differ significantly from the other treatments. Shrimp fed the Fish diet presented a
Table 2 - Mean ( \pm SD), maximum and minimum values of temperature, salinity, $\mathrm{pH}$, total ammonia and nitrite during the culture of Farfantepenaeus paulensis for 28 days.

\begin{tabular}{lccc}
\hline & Mean $\pm \mathrm{SD}$ & Minimum & Maximum \\
\hline Temperature $\left({ }^{\circ} \mathrm{C}\right)$ & $25.2 \pm 0.3$ & 24.0 & 27.2 \\
Salinity & $29 \pm 1$ & 28 & 31 \\
$\mathrm{pH}$ & $8.21 \pm 0.09$ & 7.91 & 8.39 \\
Total ammonia $(\mathrm{mg} \mathrm{N}-\mathrm{AT} / \mathrm{l})$ & $0.13 \pm 0.10$ & 0 & 0.35 \\
Nitrite $\left(\mathrm{mg} \mathrm{N}^{\left.-\mathrm{NO}_{3} / \mathrm{l}\right)}\right.$ & $0.03 \pm 0.02$ & 0 & 0.08 \\
\hline
\end{tabular}

significantly lower instantaneous growth rate $(G)$ than those fed the diets Squid, Mussel, Mix 1 and Mix 2. FCR and PER were significantly higher for the Mix 2 treatment in comparison to the Fish diet, while no differences were found between the other treatments.

\section{DISCUSSION}

The source of protein is one of the most important criteria in the formulation of aquaculture feeds (CHO et al., 1985). Currently the most important protein sources in crustacean feeds are those derived from aquatic animals. This is expected as marine animals tend to be the natural prey of crustaceans (HOUSER \& AKIYAMA, 1997). Among marine protein sources, fish meal is by far the most common ingredient in shrimp feeds as it supplies essential amino

Table 1 - Formulation and proximate composition of the experimental diets.

\begin{tabular}{|c|c|c|c|c|c|}
\hline & \multicolumn{5}{|c|}{ Experimental diets } \\
\hline & Fish & Squid & Mussel & Mix 1 & Mix 2 \\
\hline \multicolumn{6}{|l|}{ Formulation (g) } \\
\hline Whole hen eggs & 220 & 220 & 220 & 220 & 220 \\
\hline Wheat flour & 50 & 50 & 50 & 50 & 50 \\
\hline Defatted milk powder & 15 & 15 & 15 & 15 & 15 \\
\hline Sodium chloride & 15 & 15 & 15 & 15 & 15 \\
\hline Fish meal & 400 & - & - & 240 & 160 \\
\hline Squid meal & - & 400 & - & 80 & 120 \\
\hline Mussel meal & - & - & 400 & 80 & 120 \\
\hline \multicolumn{6}{|c|}{ Proximate composition (\% dry matter) } \\
\hline Moisture content & 6.1 & 5.6 & 5.9 & 5.7 & 5.9 \\
\hline Crude protein & 49.0 & 47.8 & 47.9 & 48.3 & 47.1 \\
\hline Crude fat & 15.2 & 14.2 & 13.8 & 14.7 & 14.5 \\
\hline Ash & 10.3 & 9.6 & 10.0 & 9.7 & 10.1 \\
\hline Crude fiber & 0.9 & 1.2 & 1.6 & 1.3 & 1.1 \\
\hline Nitrogen free extract & 24.6 & 27.2 & 26.7 & 26.0 & 27.2 \\
\hline Gross energy (kcal/g) & 5197 & 5141 & 5088 & 5167 & 5130 \\
\hline
\end{tabular}


Table 3 - Mean ( \pm SD) survival, final weight and biomass, instantaneous growth rate (G), feed conversion (FCR) and protein efficiency ratios (PER) of Farfantepenaeus paulensis fed diets containing different marine protein sources during 28 days. Values within a given row bearing a different superscript letter are significantly different $(\mathrm{P}<0.05)$.

\begin{tabular}{|c|c|c|c|c|c|}
\hline & \multicolumn{5}{|c|}{ Experimental diets } \\
\hline & Fish & Squid & Mussel & Mix 1 & Mix 2 \\
\hline Survival & $87.8^{\mathrm{ab}}$ & $90.3^{a b}$ & $82.0^{b}$ & $91.7^{\mathrm{ab}}$ & $93.0^{\mathrm{a}}$ \\
\hline$(\%)$ & \pm 3.5 & \pm 6.3 & \pm 7.6 & \pm 1.1 & \pm 2.7 \\
\hline \multirow{2}{*}{ Final weight (mg) } & $28.4^{b}$ & $38.1^{\mathrm{ab}}$ & $32.5^{\mathrm{ab}}$ & $37.3^{a b}$ & $40.4^{\mathrm{a}}$ \\
\hline & \pm 1.4 & \pm 6.9 & \pm 3.6 & \pm 4.9 & \pm 7.0 \\
\hline Biomass & $2.40^{b}$ & $3.30^{\mathrm{ab}}$ & $2.60^{\mathrm{ab}}$ & $3.28^{\mathrm{ab}}$ & $3.56^{\mathrm{a}}$ \\
\hline (g) & \pm 0.14 & \pm 0.92 & \pm 0.44 & \pm 0.40 & \pm 0.66 \\
\hline \multirow{2}{*}{$\mathrm{G}$} & $0.086^{b}$ & $0.096^{\mathrm{a}}$ & $0.092^{\mathrm{a}}$ & $0.096^{\mathrm{a}}$ & $0.099^{\mathrm{a}}$ \\
\hline & \pm 0.002 & \pm 0.007 & \pm 0.003 & \pm 0.005 & \pm 0.006 \\
\hline \multirow{2}{*}{ FCR } & $2.69^{b}$ & $2.08^{\mathrm{ab}}$ & $2.53^{\mathrm{ab}}$ & $1.98^{\mathrm{ab}}$ & $1.84^{\mathrm{a}}$ \\
\hline & \pm 0.17 & \pm 0.69 & \pm 0.45 & \pm 0.23 & \pm 0.31 \\
\hline \multirow{2}{*}{ PER } & $0.76^{b}$ & $1.07^{\mathrm{ab}}$ & $0.84^{\mathrm{ab}}$ & $1.08^{\mathrm{ab}}$ & $1.15^{\mathrm{a}}$ \\
\hline & \pm 0.04 & \pm 0.30 & \pm 0.14 & \pm 0.13 & \pm 0.21 \\
\hline
\end{tabular}

acids, such as methionine and lysine, which are usually deficient in plant proteins (DE SILVA \& ANDERSON, 1994). However, because of the high cost and short supply of good quality fish meal expected to be available in the near future (NAYLOR et al., 2000) and the high content of phosphorus, one of the main nutrients responsible for water eutrophication (BERGHEIM \& SVEIER, 1995; BARRIAS \& OLIVA-TELES, 2000), the replacement of fish meal by alternative protein sources has been thoroughly researched (BERGHEIM \& SVEIER, 1995; EL SAYED, 1998; BARRIAS \& OLIVA-TELES, 2000).

Despite the widespread use of fish meal in aquatic feeds, results from the present study demonstrate that growth performance and feed utilization of shrimp fed the fish meal-based diet tended to be inferior to those fed other protein sources or their combinations. This indicates that among marine protein sources fish meal may not be the best protein source for $\boldsymbol{F}$. paulensis.

It is well known that the efficiency of feed utilization and consequently growth performance is affected the quality of dietary protein (TACON, 1987). Protein quality is usually determined by its ability to support growth and development of the animal, which in turn depends primarily on the composition of essential amino acids (EAA). In this study, protein quality was indirectly inferred through the estimation of PER. The lowest PER (hence lower protein quality) observed for shrimp fed the Fish diet can probably be attributed to the relatively lower EAA pattern in comparison to the other experimental diets.
Results from the present experiment also indicate that squid meal may be a better protein source than fish meal for $\boldsymbol{F}$. paulensis. For several species of penaeid shrimp squid meal is considered an effective protein source (FENUCCI et al., 1980; CRUZ-RIQUE et al., 1987). CRUZ-SUAREZ \& GUILLAUME (1983) found that the supplementation of a basal diet with a protein fraction obtained from squid (hence named squid protein fraction, SPF) enhanced the growth of Marsupenaeus japonicus, but as the amino acid profile of the SPF supplemented diet did not differ from the basal diet, they concluded that the SPF contained a growth promoting factor. In the present study, this unknown growth factor conferred by squid meal may have played a significant role in the superior results observed with the squid meal-based diet, although this superiority could also be explained by the higher nutritional value of squid meal, particularly its EAA profile. Further research is needed to test additional protein sources of marine origin as well as plant proteins.

\section{CONCLUSIONS}

Among the individual marine protein sources tested in the present study, fish meal was the worst protein source for $\boldsymbol{F}$. paulensis. Its use as the main protein source in the formulation of feeds for $\boldsymbol{F}$. paulensis must be carefully considered. On the other hand, the inclusion of squid meal resulted in higher growth rates than fish meal, while feeds containing a mixture of protein sources tended to be better utilized 
by $\boldsymbol{F}$. paulensis and therefore resulted in superior growth and a more efficient feed utilization than those containing a single protein source. These differences may probably be related to the more balanced nutritional composition of diets containing various ingredients, particularly their EAA pattern.

\section{ACKNOWLEDGEMENTS}

R.C. Speck had financial support from Fundação de Amparo a Pesquisa do Estado do Rio Grande do Sul - FAPERGS. R.O. Cavalli is a research fellow of Conselho Nacional de Desenvolvimento Científico e Tecnológico - CNPq, Brazil.

\section{REFERENCES}

AKIYAMA, D.; DOMINY, W.G.; LAWRENCE, A.L. Penaeid shrimp nutrition. In: FAST, A.W., LESTER, L.J. Marine shrimp culture; principles and practices. Amsterdam : Elsevier, 1992. p.535-568

AOAC. Official methods of analysis. Arlington : Association of Official Analytical Chemists, 1984. 1141p.

BAGENAL, T.B. Methods for assessment of fish production in fresh waters. Oxford : Blackwell Science, 1978. 365p.

BARBIERI, R.C. La acuicultura brasileña: situación actual y perspectivas futuras. Panorama Acuícola, v.4, p.24-25, 1999.

BARRIAS, C.; OLIVA-TELES, A. The use of locally produced fish meal and other dietary manipulations in practical diets for rainbow trout Oncorhyncus mykiss (Walbaum). Aquaculture Research, v.31, p.213-218, 2000

BENDSCHNEIDER, K.; ROBINSON, R.J. A new spectrophotometric method for the determination of nitrite in seawater. Journal of Marine Research, v.11, p.87-96, 1952.

BERGHEIM, A.; SVEIER, H. Replacement of fish meal in salmonid diets by soya meal reduces phosphorus excretion. Aquaculture International, v.3, p.265-268, 1995.

BUENO, S.L.S. Técnicas, procedimentos e manejos para a produção de pós-larvas de camarões peneídeos. Brasilia : CIRM, 1989. 107p.

CHO, C.Y.; SLINGER, S.J.; BAYLEY, H.S. Bioenergetics of salmonid fishes: energy intake, expenditure and productivity. Comparative Biochemistry and Physiology, v.73B, p.25-41, 1982.

CHO, C.Y.; COWEY, C.B.; WATANABE, T. Fish nutrition in Asia: methodological approaches to research and development. Ottawa : IDRC, $1985.154 \mathrm{p}$.

CRUZ-RIQUE, L.E. et al. Squid protein effect on growth of four penaeid shrimp. Journal of the World Aquaculture Society, v.18, n.4, p.209-217, 1987.

CRUZ-SUAREZ, L.E.; GUILLAUME, J. Facteur de croissance inconnu de la farine de calamar pour la crevette japonaise: localisation de ce facteur. Copenhagen : Conseil International pour la l'Exploration de la Mer C.M., 1983. F:14.
DE SILVA, S.S.; ANDERSON, T.A. Fish nutrition in aquaculture. London : Chapman and Hall, 1994. 254p.

DIAZ, R.O.R. Exigências de proteína e energia bruta para juvenis de Penaeus paulensis (Pérez Farfante, 1967) submetidos a diferentes salinidades. 1995. 56f. Dissertation (Master in Aquaculture) - Universidade Federal de Santa Catarina.

EL SAYED, A-F.M. Total replacement of fish meal with animal protein sources in nile tilapia, Oreochromis niloticus (L.), feeds. Aquaculture Research, v.29, p.275-280, 1998.

FENUCCI, J.; ZEIN-ELDIN, Z.P.; LAWRENCE, A. The nutritional response of two penaeid species to various levels of squid meal in prepared feed. Proceedings of the World Mariculture Society, v.11, p.403-409, 1980.

HOUSER, R.H.; AKIYAMA, D.M. Feed formulation principles. In: D'ABRAMO, L.R.; CONKLIN, D.E.; AKIYAMA, D.M. Crustacean nutrition. Baton Rouge : World Aquaculture Society, 1997. p.493-519.

ITO, K. et al. Substituição da proteína de origem animal pela de origem vegetal em dietas para o camarão Penaeus paulensis. In: SIMPÓSIO BRASILEIRO DE AQÜICULTURA, 9., 1996, Sete Lagoas. Anais... Sete Lagoas : Associação Brasileira de Aqüicultura, 1996. V.1, p.13.

LEMOS, D.; EZQUERRA, J.M.; GARCIA-CARREÑO, F.L. Protein digestion in penaeid shrimp: digestive proteinases, proteinase inhibitors and feed digestibility. Aquaculture, v.186, p.89-105, 2000.

MARCHIORI, M.A. Guia ilustrado de maturação e larvicultura do camarão-rosa Penaeus paulensis Pérez-Farfante, 1967. Rio Grande : FURG, 1996. 79p.

MARCHIORI, M.A. et al. Estudos sobre a alimentação do camarão rosa Penaeus paulensis. Atlantica, Rio Grande, v.5, p.43-48, 1982.

NAYLOR, R.L. et al. Effect of aquaculture on world fish supplies. Nature, v.405, p.1017-1024, 2000.

NEW, M.B.; SINGHOLKA, S. Freshwater prawn farming : a manual for the culture of Macrobrachium rosenbergii. Rome: FAO, 1995. (FAO Fisheries Technical Paper n.225 Rev. 1).

OLIVERA, A. et al. Crescimento do "camarão-rosa" Penaeus paulensis no repovoamento da Lagoa de Ibiraquera, Santa Catarina, Brasil. In: SIMPÓSIO BRASILEIRO SOBRE CULTIVO DE CAMARÃO, 4., 1993, João Pessoa. Anais... João Pessoa : MCR Aquacultura, 1993. V.1, p.439-451.

PEIXOTO, S.; WASIELESKY, W.; LOUZADA, L. Comparative analysis of pink shrimp, Farfantepenaeus paulensis, and Pacific white shrimp, Litopenaeus vannamei, culture in extreme southern Brazil. Journal of Applied Aquaculture, v.14, n.1, 2003 (In press).

ROCHA, I.P.; RODRIGUES, J. A carcinicultura brasileira em 2002. Revista da ABCC, v.5, n.1, p.30-45, 2003.

RODRIGUES, J.B.R. Fontes e níveis de proteína em rações para camarão Penaeus paulensis Pérez-Farfante, 1967 e sua viabilização no cultivo em viveiro. 1985. $80 \mathrm{f}$. 
Dissertation (Master in Oceanography) - Universidade Federal de Pernambuco.

SOLORZANO, L. Determination of ammonia in natural water by the phenolhypochlorite method. Limnology and Oceanography, v.14, p.799-801, 1969.
TACON, A.G.J. The nutrition and feeding of farmed fish and shrimp - A training manual. 1. The essential nutrients. Brasilia: FAO, 1987. 117p. (FAO Field document).

WASIELESKY, W. et al. O camarão rosa nos cercados do sul do Brasil. Panorama da Aqüicultura, v.12, n.73, p.31-35, 2002. 